\title{
EFFECT OF SOME AGRICULTURAL OPERATIONS ON THE LEVEL OF INFESTATION WITH RED PALM CHECKED WEEVIL Rhynchophorus ferrugineus (OLIVIER) IN DATE PALM FARMS IN EGYPT \\ Abbass, M. K. ${ }^{1}$ and E. G. Gadalla ${ }^{2}$

1- Plant Protection Research Institute, Agric., Res., Center, Giza, Egypt.

2- Central Lab. of Date Palm Res. and Development, Agric. Res. Centre, Egypt

\begin{abstract}
The red palm weevil, Rhynchophorus ferrugineus(Olivier.) (Coleoptera:Curculionidae) (Oliv.) is the most serious and destructive insect pest for date palm trees. The study carried out in date plantations of Nobaria , Beheira Governorate. Results indicated that the total percentages of palms infestation were $25 \%$ and $16.8 \%$ during season 2012 and 2013,respectvely. The palm trees which contain air roots were highly infestation compared palms without air roots arrived $44.8 \%$ and $47.6 \%$ infestation during two years, respectively. High percentage of infestation recorded at $0.0-1.0 \mathrm{~m}$ above ground surface low infestation occurred in top tree ranged $7.1-8 \%$ infestation. High number of infested palms found in the farm more irrigation. The available humidity under trees of ten vary according to irrigation methods. High number of palm infested found in trees that contain air offshoots compared (with removed offshoots with treatment fogging using sulfur powder after removing), these recorded $11.6 \%$ and $33.3 \%$ with removal and no removal offshoots. No significant differences between yield product in each healthy palm and infested date palm during two seasons.
\end{abstract}

\section{INTRODUCTION}

Date palm, Phoenix dactylifera L. (Palmacae) is the most common and widely cultivated in the arid regions of the Middle East and North Africa. Abdel-Megeed, et al. (2004) Arab countries however, contain $78.3 \%$ of the total world date palm trees which demonstrate $75 \%$ of the production. The red palm weevil is one of the major and destructive pests of palm trees. In the Arabian Peninsula the RPW was first recorded in the United Arab Emirates in 1985, Saudi Arabia in 1986, Qatar in 1989, Kuwait in 1993, Bahrain in 1995 and Oman in 1993. In Egypt, the introduction of RPW was caused by an importation of offshoots from the United Arab Emirates. RPW was first discovered in date palms in the Governorate of Ismailia in 1992Saleh, (1992) and El -Sebay (2007) mentioned that about 215652 trees were infested until 2000. Represented $2.2 \%$ of whole number of palm trees in Egypt .About 59857 trees were completely removed represented $0.6 \%$ of the whole number of trees .Due to extensive use of insecticides, spraying and injection the total number of applied chemicals was about 272 ton till years 2000 . While other cultural techniques, such as irrigation or pruning, cannot be considered as control methods, their effect on $R$. ferrugineus cannot be neglected and should be considered in any IPM program against these pests. Adult $R$. 
ferrugineus seem to use moist soil as temporary shelter and there are reports that flood irrigation increases infestation in date palm orchards (Aldryhim\& Khalil, 2003; Aldryhim\& Al-Bukiri, 2003). The same can be true with sprinkle irrigation. Therefore, farmers are advised to prevent wetting the stripe next to the offshoots (Soroker et al., 2012). R. ferrugineus is preferentially attracted by wound-emitted volatiles and oviposits in soft tissue, For date palm trees, it is suggested to cover the wounds with pitch or with chemicals that efficiently seal and dry the wounded tissue (Soroker et al., 2012). The present work aimed to evaluate of different effect agricultural operations (survey, irrigation,, air roots and air offshoots on the level of infestation in red palm weevil Rhynchophorus ferrugineus in date palm farms.

\section{MATERIALS AND METHODS}

The present study was carried out in farms cultivated with date palm trees age ranged from 10 to 13 years at Nobaria ,Beheira Governorate, During two seasons 2012 and 2013. The degree of infestation depends on the size of the oozing, as follows:

- low iinfestation: Little of oozing and no found cocoons in the infested palm trees.

- Moderate of infestation: Large volume of oozing contain and found cocoon inside infested trees aalso adult inside cocoon.

- High infestation : Large volume of oozing contain ,found cocoons, adults inside cocoons, adults outside cocoon and cavities.

1-Survey this work conducted for one time each one month to record the number of healthy and infested palms place of infested palm, height of infestation, site palm that contain air roots or no during two year 2012 and 2013. The infested palms were treated of listed pesticides.

2-Effect of number of times drip irrigation on the infested rate of date palm by red palm weevil

To study the number of times drip irrigation on infestation rate. On orchards of date palm was chosen and divided into two division (farms)The first farm was irrigated three times a week and the second farm was irrigated one time each two week was record. The number of infested palm infestation during two seasons

3-The effect of the removal of air offshoots and fogging on infestation rate

The air offshoots removed from some date palms (at rate 5 trees monthly), the place of removed offshoots treated using sulfur powder. The number and percentage of infestation in both trees which were removal un removal of air offshoots, during two years were recorded.

4-Effect of degree of infestation on production of date palm

Two degree of infestation (low and moderate infestation) and uninfected trees (control) were used. Ten replicates of each treatment contain, Besides 5 date palm trees during two seasons and treatment of infested palms after directly infestation by pesticide 


\section{RESULTS AND DISCUSSION}

\section{1- Survey of palm infestation}

Date presented in Table (1) showed that the number of palm healthy and infested palm, height infestation, existence air roots or no and The number of times repeated on the same palm during two years 2012 and 2013.The results appeared that percentage of palm infestation were $25 \%$ and $16.6 \%$ of total date palm during two seasons and more of palm low infestation may the periodic inspection. The highly palm infestation recorded during March. August and November during two season .The number of infected palm may reach 2 to 4 area infestation special date palm contain air roots. The infestations of palm trees containing air roots highly infestation compared with palm not contain roots arrived $44.8 \%$ and $47.6 \%$ from total infestation of palm trees respectively. The high percentage of infestation recorded on height $0-1 \mathrm{~m}$ above ground surface during the two years of study and low percentage on height 2 to 3 meters from the surface of the ground. The infestation in top head arrived $7.1 \%$ and $8 \%$ number of palm infestation. Sallam et al (2012) found that nearly $90 \%$ of the infestations occurred on the palm trunk between $0-100 \mathrm{~cm}$ from the ground surface with maximum infestations (36\%) being recorded in the age group of 6 to 10 years.

Table (1): Number of healthy, and infested palm, height of infestation, air roots and number of times repeated infestation on the same palm during two years 2012 and 2013

\begin{tabular}{|c|c|c|c|c|c|c|c|c|c|c|c|c|c|c|c|c|}
\hline \multicolumn{9}{|c|}{2012} & \multicolumn{8}{|c|}{2013} \\
\hline \multirow[t]{2}{*}{ Month } & \multicolumn{3}{|c|}{$\begin{array}{l}\text { Degree of } \\
\text { infestation }\end{array}$} & \multirow[t]{2}{*}{$\begin{array}{l}\text { Air } \\
\text { roots }\end{array}$} & \multirow[t]{2}{*}{$\begin{array}{c}\text { Result } \\
\text { of } \\
\text { injection }\end{array}$} & \multicolumn{3}{|c|}{$\begin{array}{l}\text { Height of } \\
\text { infestation } \\
\text { site }\end{array}$} & \multicolumn{3}{|c|}{$\begin{array}{l}\text { Degree of } \\
\text { infestation }\end{array}$} & \multirow[t]{2}{*}{$\begin{array}{c}\text { Air } \\
\text { roots }\end{array}$} & \multirow[t]{2}{*}{$\begin{array}{c}\text { Result } \\
\text { of } \\
\text { injection }\end{array}$} & \multicolumn{3}{|c|}{$\begin{array}{c}\text { Height of } \\
\text { infestation } \\
\text { site }\end{array}$} \\
\hline & Low & \begin{tabular}{|l|}
$\mathbf{M}$ \\
\end{tabular} & H & & & $0-1 \mathrm{~m}$ & $1-2 m$ & 2- & Low & M & H & & & $0-1 \mathrm{~m}$ & $1-2 m$ & 2- \\
\hline Jan. & 5 & 3 & 4 & 4 & 10 & 8 & 2 & & 3 & 2 & 2 & 2 & 6 & 7 & 0 & \\
\hline Feb. & 8 & 5 & 2 & 6 & 12 & 13 & 2 & 0 & 5 & 2 & 1 & 5 & 6 & 7 & 1 & 0 \\
\hline Mar. & 10 & 8 & 1 & 10 & 15 & 17 & 2 & 0 & 6 & 4 & 1 & 7 & 9 & 10 & 0 & 1 \\
\hline Apr. & 5 & 2 & 1 & 4 & 7 & 6 & 1 & 1 & 2 & 1 & 3 & 2 & 4 & 4 & 1 & 1 \\
\hline May. & 3 & 4 & 2 & 5 & 8 & 6 & 2 & 1 & 3 & 0 & 2 & 2 & 4 & 4 & 1 & 1 \\
\hline Jun. & 4 & 3 & 1 & 5 & 5 & 5 & 2 & 1 & 0 & 5 & 2 & 7 & 5 & 7 & 0 & 0 \\
\hline \begin{tabular}{|l} 
July. \\
\end{tabular} & 5 & 1 & 0 & 2 & 5 & 6 & 0 & 0 & 4 & 2 & 1 & 4 & 6 & 6 & 0 & 1 \\
\hline Aug. & 8 & 1 & 0 & 4 & 7 & 6 & 3 & 0 & 5 & 3 & 1 & 3 & 8 & 7 & 1 & 1 \\
\hline Sep. & 1 & 2 & 2 & 2 & 2 & 2 & 1 & 2 & 2 & 0 & 0 & 1 & 2 & 2 & 0 & 0 \\
\hline Oct. & 5 & 1 & 1 & 4 & 5 & 2 & 2 & 3 & 4 & 1 & 1 & 2 & 5 & 4 & 1 & 1 \\
\hline Nov. & 5 & 4 & 8 & 7 & 14 & 5 & 1 & 1 & 3 & 2 & 1 & 3 & 6 & 4 & 2 & 0 \\
\hline Dec. & 2 & 3 & 5 & 3 & 9 & 6 & 3 & 1 & 3 & 4 & 3 & 2 & 8 & 7 & 2 & 1 \\
\hline Total & 61 & 37 & \begin{tabular}{|l|}
27 \\
\end{tabular} & 56 & 99 & 82 & 21 & 10 & 40 & 26 & 18 & 40 & 69 & & 9 & 6 \\
\hline
\end{tabular}

L Low infestation M moderate infestation H Highly infestation

\section{2- Effect of Irrigation on the infection rate of red palm weevil}

Results obtained in Table (2) indicated that high number of palm infestation were found in first farm which more irrigated the availability of humidity down the date palm compared with second farm. Number of palms 125 and 84 date palms in the first farm, 7 and 17 date palm infestations in the second farm. Salam et al (2012) found that ---88\% of the infestation in the Al- 
Hassa oasis was recorded in plantations that were Flood-irrigated as compared to 9.6 and $2.4 \%$ infestation in plantations that were irrigated through open basins and drip lines, respectively.

3-The effect of the removal of air offshoots and fogging on infection rate Data presented in Table (3) revealed that the high number of palm infestation found in air offshoots compared removed offshoots with treatment fogging using sulfur powder after removal. The highly percentage of infestation with not remove of air offshoots recorded $33.3 \%$ and $40 \%$ during two season respectively while low percentage infestation with The removal of air offshoots and treatment by using sulfur powder recorded $11.60 \%$ and $15 \%$ during the two years 2012 and 2013.

\section{4- Effect of infestation degree of and on product of yield}

Date arranged in Table (4) cleared the effect of the low and moderate infestation with red palm weevil on yield of dates, during the two years 2012 and 2013 .In the date palm healthy ranged between $40-120 \mathrm{~kg}$ and $55-150$ $\mathrm{Kg}$ with the mean of $85 \mathrm{Kg}$ and $108 \mathrm{Kg}$ during the two seasons 2012 and 2013 .In the date palm (low infestation) during two years 2012 and 2013 ranged between $50-110 \mathrm{~kg}$ and $45-130 \mathrm{Kg}$ with the mean $80 \mathrm{Kg}$ and 95 $\mathrm{Kg}$.The date palm moderate infestation during two years 2012 and 2013 ranged between 55-105 kg and $59-145 \mathrm{Kg}$ with the mean $75 \mathrm{Kg}$ and 100 . Statistical analysis between the production of healthy and infested palms (low and moderate) during two seasons show no significant difference

Table (2) .The effect of the irrigation method on the infestation rate

\begin{tabular}{|l|c|c|c|c|c|c|c|c|}
\hline \multicolumn{4}{|c|}{$\mathbf{2 0 1 2}$} & \multicolumn{4}{c|}{$\mathbf{2 0 1 3}$} \\
\hline \multirow{2}{*}{ Month } & \multicolumn{2}{|c|}{ Farm1 } & \multicolumn{2}{c|}{ Farm 2 } & \multicolumn{2}{c|}{ Farm1 } & \multicolumn{2}{c|}{ Farm2 } \\
\cline { 2 - 9 } & $\begin{array}{c}\text { No of palm } \\
\text { infestation }\end{array}$ & $\begin{array}{c}\text { \% } \\
\text { infestation }\end{array}$ & $\begin{array}{c}\text { No of } \\
\text { palm } \\
\text { infestation }\end{array}$ & $\begin{array}{c}\text { \% } \\
\text { infestation }\end{array}$ & $\begin{array}{c}\text { No of } \\
\text { palm } \\
\text { infestation }\end{array}$ & $\begin{array}{c}\text { \% } \\
\text { infestation }\end{array}$ & $\begin{array}{c}\text { No of } \\
\text { palm } \\
\text { infestation }\end{array}$ & $\begin{array}{c}\% \\
\text { infestation }\end{array}$ \\
\hline Jan. & 12 & 2.4 & 1 & 0.2 & 7 & 1.4 & 2 & 0.4 \\
\hline Feb. & 15 & 3 & 0 & 0 & 8 & 1.6 & 3 & 0.6 \\
\hline Mar. & 19 & 3.8 & 0 & 0 & 11 & 2.2 & 2 & 0.4 \\
\hline Apr. & 8 & 1.6 & 2 & 0.4 & 6 & 1.2 & 1 & 0.2 \\
\hline May. & 9 & 1.8 & 1 & 0.2 & 5 & 1 & 1 & 0.2 \\
\hline Jun. & 8 & 1.6 & 0 & 0 & 7 & 1.4 & 0 & 0 \\
\hline July. & 6 & 1.2 & 0 & 0 & 7 & 1.4 & 0 & 0 \\
\hline Aug. & 9 & 1.8 & 0 & 0 & 9 & 1.8 & 2 & 0.4 \\
\hline Sep. & 5 & 1 & 2 & 0.4 & 2 & 0.4 & 2 & 0.4 \\
\hline Oct. & 7 & 1.4 & 0 & 0 & 6 & 1.2 & 0 & 0 \\
\hline Nov. & 17 & 3.4 & 0 & 0 & 9 & 1.8 & 1 & .0 .2 \\
\hline Dec. & 10 & 2 & 1 & 0.2 & 7 & 1.4 & 3 & 0.6 \\
\hline Total & 125 & 25 & 7 & 1.4 & 84 & 16.8 & 17 & 3.4 \\
\hline
\end{tabular}


Table (3) .The effect of the removal of air offshoots on the infestation rate

\begin{tabular}{|c|c|c|c|c|c|c|c|c|}
\hline & \multicolumn{4}{|c|}{$\begin{array}{l}\text { The removal of air offshoots and } \\
\text { treatment by using sulfur powder }\end{array}$} & \multicolumn{4}{|c|}{ No remove of air offshoots } \\
\hline & \multicolumn{2}{|c|}{2012} & \multicolumn{2}{|c|}{2013} & \multicolumn{2}{|c|}{2012} & \multicolumn{2}{|c|}{2013} \\
\hline & $\begin{array}{l}\text { No of } \\
\text { palm }\end{array}$ & $\begin{array}{c}\% \\
\text { infestation }\end{array}$ & $\begin{array}{l}\text { No of } \\
\text { palm }\end{array}$ & $\begin{array}{c}\% \\
\text { infestation }\end{array}$ & $\begin{array}{l}\text { No of } \\
\text { palm }\end{array}$ & $\begin{array}{c}\% \\
\text { infestation }\end{array}$ & $\begin{array}{l}\text { No of } \\
\text { palm }\end{array}$ & \begin{tabular}{|c|}
$\%$ \\
infestation
\end{tabular} \\
\hline Jan. & 5 & 20 & 5 & 20 & 5 & 20 & 5 & 40 \\
\hline Feb. & 5 & 20 & 5 & 0 & 5 & 40 & 5 & 60 \\
\hline Mar. & 5 & 20 & 5 & 0 & 5 & 40 & 5 & 40 \\
\hline Apr. & 5 & 0 & 5 & 20 & 5 & 20 & 5 & 40 \\
\hline May. & 5 & 0 & 5 & 40 & 5 & 40 & 5 & 60 \\
\hline Jun. & 5 & 20 & 5 & 0 & 5 & 20 & 5 & 20 \\
\hline July. & 5 & 0 & 5 & 0 & 5 & 40 & 5 & 40 \\
\hline Aug. & 5 & 0 & 5 & 0 & 5 & 20 & 5 & 60 \\
\hline Sep. & 5 & 40 & 5 & 40 & 5 & 20 & 5 & 20 \\
\hline Oct. & 5 & 0 & 5 & 20 & 5 & 40 & 5 & 40 \\
\hline Nov. & 5 & 0 & 5 & 20 & 5 & 60 & 5 & 20 \\
\hline Dec. & 5 & 20 & 5 & 40 & 5 & 40 & 5 & 20 \\
\hline Total & & 11.67 & & 15 & & 33.33 & & 40 \\
\hline
\end{tabular}

Table (4). Effect of degree of infestation on product of date palm

\begin{tabular}{|c|c|c|c|c|}
\hline \multirow{3}{*}{ Years } & \multirow{3}{*}{$\begin{array}{l}\text { No of } \\
\text { palm }\end{array}$} & \multicolumn{3}{|c|}{ Degree of infestation on product of date palm } \\
\hline & & Low infestation & Moderate infestation & Health palm \\
\hline & & $\begin{array}{l}\text { Mean yield / } \\
\text { palm (Kg) }\end{array}$ & $\begin{array}{c}\text { No of palm } \\
\text { Mean yield / palm }(\mathrm{Kg})\end{array}$ & $\begin{array}{c}\text { No of palm } \\
\text { Mean yield / palm }(\mathrm{Kg})\end{array}$ \\
\hline 2012 & 10 & 80 & 75 & 85 \\
\hline 2013 & 10 & 90 & 100 & 108 \\
\hline
\end{tabular}

\section{CONCLUSION}

The early detection of infestation , treatment of palm infestation ,avoid the formation air roots, get rid of the air offshoots and treatment by anywhere removal and moderation in irrigation leads to prevention large proportion of the palms from the infestation, thereby reduce the use of pesticides .

\section{REFERENCES}

Abdel-Megeed, M.E.; H.A. Zedan and G.B. El-Saadany (2004). The integrated management for controlling pests of date palm.Kenza Group Pub. Egypt, 483 pp (in Arabic)

Aldryhim Y \& Al-Bukiri S (2003). Effect of irrigation on within-grove distribution of red palm weevil Rhynchophorous ferrugineus. Sultan Qaboos University Journal for Scientific Research - Agriculturaland Marine Sciences 8: 47-49. 
Aldryhim Y \& Khalil A (2003).Effect of humidity and soil type on survival and behaviour of red palm weevil Rhynchophorus ferrugineus (Oliv.) adults.Sultan Qaboos University Journal for Scientific Research (Agricultural and Marine Sciences) 8: 87-90.

El-Sebay,Y (2007): Studies on the Infestation of Red Palm Weevil Rhynchophorus ferrugineus (Olv.) In Egypt.Ist International Conf. of Date Palm. PPRI,. Egypt. 85(1A):131-162

Saleh, M.R.A. (1992). Red palm weevil attacking date palm trees in limited areas of Egypt at the present time and how can be eradicated from these areas. Report of Plant Protection Department, Faculty of Agriculture, Zagazig University: 20 pp (Arabic Language

Sallam, A.A H.A.F.El-Shafie and Al-Abdan S.( 2012): Influence of farming practices on infestation by red palm weevil Rhynchophorus ferrugineus (Olivier) in date palm: a case study International Research Journal of Agricultural Science and Soil Science (ISSN: 2251-0044) Vol. 2(8) pp. 370-376,

SAS Institute 1985 SAS user s guide: statistics ,5thEd SAS Institute, Cary ,NC

Soroker V, Oren H, Haberman A and Cohen Y, (2012): To live with the red palm weevil Rhynchophorus ferrugineus. AlonHanotea 65: 24-27 (in Hebrew) (2012)

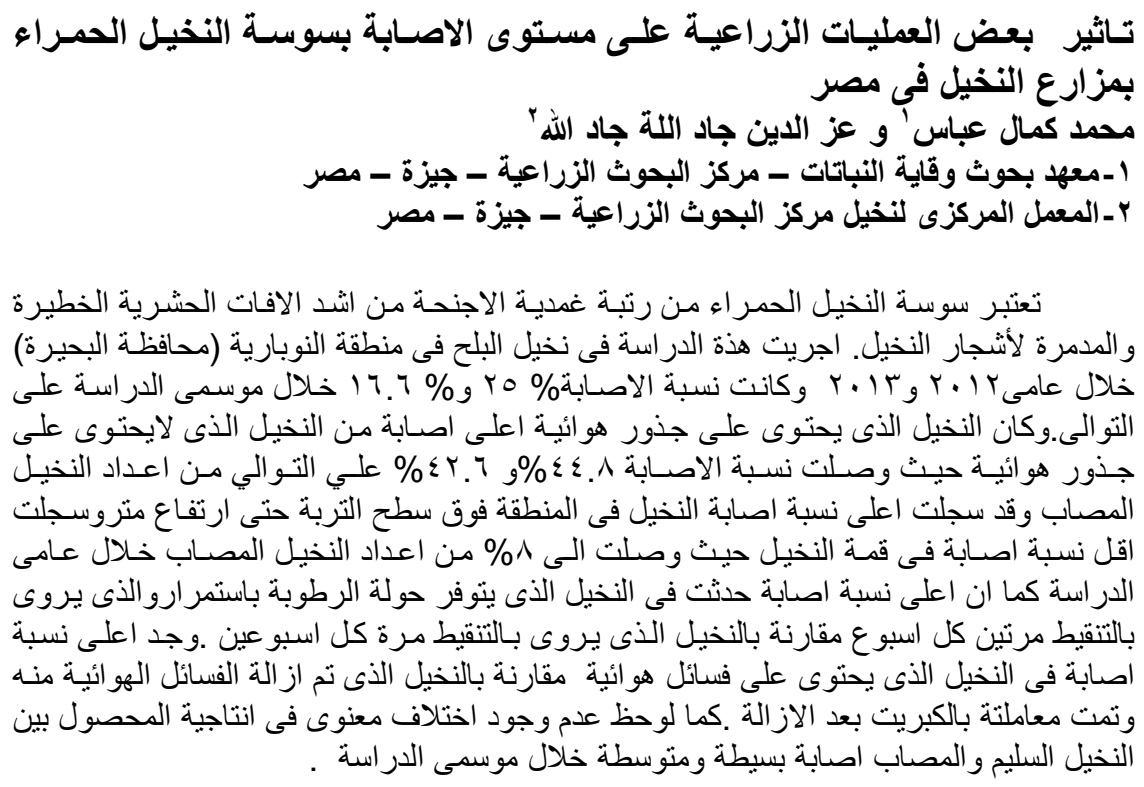

